\title{
Candida on oral cavity of pediatric individuals with ALL and its susceptibility to nystatin and amphotericin $B$
}

\author{
Candida na cavidade oral de indivíduos pediátricos com LLA \\ e sua susceptibilidade à nistatina e à anfotericina B
}

\author{
Larissa Cavalcanti MONTEIRO' ${ }^{1}$ 0000-0002-7349-0878 \\ Isabella Lima Arrais RIBEIRO' ${ }^{1}$ iD 0000-0001-6538-6811 \\ Roberta Ferreti Bonan Dantas BATISTA ${ }^{1}$ iD 0000-0001-8737-6032 \\ Panmella Pereira MACIEL ${ }^{2}$ iD 0000-0003-0168-5833 \\ Ana Maria Gondim VALENÇA ${ }^{3}$ iD 0000-0001-8460-3981 \\ Ana Carolina Bernardes DULGHEROFF ${ }^{4}$ iD 0000-0003-2126-8623 \\ Joelma Rodrigues SOUZA ${ }^{4}$ iD 0000-0002-1456-9009 \\ Yuri Wanderley CAVALCANTI ${ }^{1}$ iD 0000-0002-3570-9904 \\ Lucio Roberto Cançado CASTELLANO ${ }^{1}$ (iD) 0000-0003-0851-5298 \\ Paulo Rogério Ferreti BONAN1 ${ }^{1}$ iD 0000-0002-4449-4343
}

\section{ABSTRACT}

Objective: The aim of this study was to evaluate the prevalence of Candida colonizationon oral cavity of pediatric individuals with acute lymphocytic leukemia (ALL) and its susceptibility/resistance to nystatin and amphotericin B. Methods: This was a cross sectional study with observational, descriptive and analytic approach. Saliva was collected from40 individuals diagnosed with ALL and from40 healthy subjects, as a comparative group, matched by age and gender with ALL group. The mean age for both groups were 8 years-old. The isolation and identification of the Candidaspecies were performed using the CHROMagarCandidaTM and confirmed by polymerase chain reaction. The samples were subjected to antifungal susceptibility by microdilution assay for nystatin and amphotericin B. Salivary alterations and chemotherapy-induced oralmucositis were evaluated using modifiedOral Assessment Guide. Results: The positivity to Candida was higher inALL individuals $(32.5 \%, 13 / 40)$ than in a comparative group $(2.5 \%, 1 / 40)(p<0.001)$. Candida albicans was the most prevalent strain (86.6\%). The mucositis was directly associated with positive Candidacolonization ( $p=0.017)$ in the ALL group but not related with salivary alterations $(p=0.479)$. Six strains of $C$. albicans $(54.5 \%)$, on ALL group, were resistant to nystatin

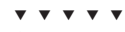

1 Universidade Federal da Paraíba, Programa de Pós-Graduação em Odontologia. Cidade Universitária, 58051-900, João Pessoa, PB, Brasil. Correspondência para / Correspondence to: PRF BONAN. E-mail: <pbonan@yahoo.com>.

2 Universidade Federal da Paraíba, Faculdade de Odontologia. João Pessoa, PB, Brasil.

3 Universidade Federal da Paraíba, Departamento de Odontologia Clínica e Social. João Pessoa, PB, Brasil

${ }^{4}$ Universidade Federal da Paraíba, Escola Técnica de Saúde, Grupo de Estudos e Pesquisas em Imunologia Humana - GEPIH. João Pessoa, PB, Brasil.

$\boldsymbol{\nabla} \boldsymbol{\nabla} \boldsymbol{\nabla}$

How to cite this article

Monteiro LC, Ribeiro ILA, Batista RFBS, Maciel PP, Valença AMG, Dulgheroff ACB, et al. Candida on oral cavity of pediatric individuals with ALL and its susceptibility to nystatin and amphotericin B. RGO, Rev Gaúch Odontol. 2019;67:e20190018. http://dx.doi.org/10.1590/1981-863 72019000183558 
and all strains were not susceptible to amphotericin B. Conclusion: Candida colonization was associated with ALL condition and with oral mucositis in these individuals. C. albicans was the prevalent strain and most samples were resistant to antifungal agents tested, nystatin and amphotericin B.

Keywords: Candida. Precursor cell lymphoblastic leukemia-lymphoma. Prevalence.

\section{RESUMO}

Objetivo: o objetivo deste estudo foi avaliar a prevalência e colonização de Candida na cavidade oral de indivíduos pediátricos com leucemia linfocítica aguda (LLA) e sua susceptibilidade/resistência à nistatina e à anfotericina B. Métodos: estudo transversal observacional com abordagem descritiva e analítica. A saliva foi coletada de 40 indivíduos diagnosticados com LLA e de 40 indivíduos saudáveis, como grupo comparativo, combinados por idade e sexo com o grupo LLA. A idade média para ambos os grupos foi de 8 anos de idade. O isolamento e a identificação das espécies de Candida foram realizados utilizando o CHROMagarCandidaTM e confirmados pela reação em cadeia da polimerase. As amostras foram submetidas a susceptibilidade antifúngica por meio de ensaio de microdiluição para nistatina e anfotericina $B$. As alterações salivares e a mucosite oral induzida por quimioterapia foram avaliadas utilizando o Guia de avaliação modificada. Resultados: A positividade para Candida foi superior aos indivíduos in situ (32,5\%, $13 / 40)$ do que em um grupo comparativo $(2,5 \%, 1 / 40)(p<0,001)$. Candida albicans foi a cepa mais prevalente (86,6\%). A mucosite foi diretamente associada à colonização positive por Candida $(p=0,017)$ no grupo LLA, mas não relacionada com alterações salivares ( $p=0,479)$. Seis estirpes de $C$. albicans $(54,5 \%)$, no grupo LLA, eram resistentes à nistatina e todas as cepas não eram suscetíveis à anfotericina B. Conclusão: A colonização por Candida foi associada à condição LLA e à mucosite oral nesses individuos. C. albicans era a cepa predominante e a maioria das amostras eram resistentes aos agentes antifúngicos testados, nistatina e anfotericina $B$.

Palavras-chaves: Candida. Leucemia-linfoma linfoblástico de células precursoras. Prevalência.

\section{INTRODUCTION}

The acute lymphocytic leukemia (ALL) represents $75 \%$ of all diagnosed leukemia in oncopediatric individuals and $25 \%$ of all malignant childhood illnesses $[1,2]$. The immunosuppression favoring related to disease, disease profile and myeloablative treatment could be associated with bacterial and fungal infections, including candidosis [2-4] In ALL patients, it could be raised in some part of chemotherapic treatment and be associated with immunosuppresionfavoring nonalbicans species colonization [4]. Other concern could be recurrent infections caused by resistant Candida species [5]. Even with the use of drugs such as nystatin and amphotericin $B$, it is highly desirable to select better treatment options defined by sensibility tests $[6,7]$. It is important because candidemia could be a critical problem in ALL patients with bad outcome and worsening of overall prognosis [3].

Highlighting the importance of knowing the profile of Candida colonization in ALL pediatric individuals and its resistance to usual treatment, the purpose of this study was to evaluate the prevalence of Candida colonizationon oral cavity of pediatric individuals with acute lymphocytic leukemia (ALL) and its susceptibility/resistance to nystatin and amphotericin B.

\section{METHODS}

The study was cross-sectional, with dual observational and descriptive characteristics approved by ethic committee of Health Centre of Federal University of Paraiba. For this study, we studied two groups. The first was ALL group, formed by 40 individuals, enrolled by census approach during 2014 and 2015. Individuals with ages ranged from 1 to 19 years old were diagnosed with ALL, at a reference oncopediatric unit located in João Pessoa, Paraíba, Brazil. The inclusion criteria were determined as ALL diagnosis and being submitted to chemotherapy or with recent history of chemotherapic treatment.

Data about hemogram with differential count, chemotherapy employed, antimicrobial drugs used, oral mucositis, xerostomia and DMFT/dmft (Decayed/Missing/ Filled Teeth) were collected from medical and dental records. Last hematological exams performed close to the salivary collection date, during the same week, were considered.

The indexes of mucositis and xerostomia were obtained from OAG (Oral Assessment Guide), modified by Cheng et al. [8] and made by calibrated examiners being dichotomized in presence/absence. Values above 9 points indicated presence of mucositis and scores 2 and 3 on saliva item, salivary alterations. The table 1 demonstrated this modified guide used in this research. 
Clinical candidosis was evaluated by calibrated examiners seeking for symptomatic white removable plaques (pseudomembranous form) over a bleeding or erythematous layer or reddish areas on mucosa associated with pain/sensibility complains (erythematous form). In cases of clinical doubt between erythematous candidosis and oral mucositis, salivary smears could be used to confirm or dismiss Candida presence in culture.

Of $40 \mathrm{ALL}, 19$ were in induction therapy, 3 in reinduction, 3 in consolidation and 15 in maintenance phases. These phases were reclassified in induction (induction/reinduction/consolidation) and maintenance phases for statistical analysis due to similarities among them. The standard chemotherapeutical protocol was BMF (Berlin-Frankfurt-Munich), 2002 [9].

A comparative group was formed by 40 individuals matched by age and gender with the ALL group. This group was formed by healthy individuals, without systemic alterations and other diseases/drugs associated to bacterial/ fungal infections or salivary complaints. Clinical candidosis was evaluated by calibrated examiners following the same criteria for ALL group. The Kappa results for the calibration of oral diagnosis were 0.877 to 1.0 (individually) and 0.844 between the evaluators [10].

\section{Isolation, Culture and Identification of Candida species}

Salivary collection was made with a sterile swab on the buccal mucosa (right and left) and tongue, in order from top to bottom, and back to forward. A standard collection using swabs with Stuart medium (Global Transport Medium Swabs, Global Trade Technology, Brazil) was made in three volunteers. Swabs were weighed before and after the salivary collection. Mean volume of salivary collection was $0.03 \mathrm{~mL}$.

After the collection transportation, the swabs were immediately seeded into plates with CHROMagarCandida ${ }^{\mathrm{TM}}$ (BD ${ }^{\mathrm{TM}}$ CHROMAGAR ${ }^{\mathrm{TM}}$ Candida, France). After seeding, plates were placed on incubator at $370 \mathrm{C}$ for 48 hours. The mean of $\mathrm{CFU} / \mathrm{mL}$ was obtained by the counting of positive growth of Candida. The CFUs were presumptively identified according to color and texture patterns. These colonies were stored at $-2{ }^{\circ} \mathrm{C}$ into Sabouraud Dextrose Broth (SDB) (KASVI ${ }^{\circledR}$, Curitiba, Brazil) supplemented by glycerol $(40 \% \mathrm{v} / \mathrm{v})$, into cryotubes $(2 \mathrm{~mL})$.

\section{Polymerase Chain Reaction (PCR) identification}

PureLink ${ }^{\mathrm{TM} G e n o m i c}$ DNA extraction kit (Invitrogen, USA) was used to extract DNA from samples. The amplification reaction was performed with a final volume of $50 \mathrm{~mL}$ containing $100 \mathrm{ng}$ of DNA, 1X buffer, $5 \mathrm{mM} \mathrm{MgCl} 2,1 \mathrm{mM}$ dNTP's, $1 \mu \mathrm{L}$ of each primer and $5 \mathrm{U}$ Taq platinum DNA polymerase (Invitrogen, Carlsbad, (A, USA). Strain identification was determined from the primer ACT1-f(TGCTGAACGTATGCAAAAGG) and ACT1-r (TGAACAATGGATGGACCAGA) (Exxtend Biotechnology Ltd., Brazil), which is a constitutive primer

Table 1. Modified OAG index used in this study (8).

\begin{tabular}{|c|c|c|c|}
\hline \multicolumn{4}{|c|}{ Score } \\
\hline Item & 1 & 2 & 3 \\
\hline Voice & Normal & Deeper or raspy & Difficulty talking or painful \\
\hline Swallow & Normal & Some pai non swallowing & Unableto swallow \\
\hline Lips & Smooth and pink and moist & Dry or cracked & Ulcerated bleeding \\
\hline Tongue & Pink and moist and papillae present & $\begin{array}{l}\text { Coated orloss of papillae with shiny } \\
\text { appearance withor without redness }\end{array}$ & Blistered or cracked \\
\hline Saliva & Watery & Thickorropy & Absent \\
\hline $\begin{array}{l}\text { Mucousmembrane } \\
\text { Palate }\end{array}$ & Pink and moist & $\begin{array}{l}\text { Reddened or coated } \\
\text { Without ulceration }\end{array}$ & $\begin{array}{l}\text { Ulceration with or without } \\
\text { bleeding }\end{array}$ \\
\hline Labial mucosa & Pink and moist & $\begin{array}{l}\text { Reddened or coated } \\
\text { Without ulceration }\end{array}$ & $\begin{array}{l}\text { Ulceration with or without } \\
\text { bleeding }\end{array}$ \\
\hline Gingiva & Pink and stippled and firm & Edematous withor without redness & $\begin{array}{l}\text { Spontaneous bleeding or } \\
\text { bleeding with pressure }\end{array}$ \\
\hline
\end{tabular}


specific for Candida albicans and from the primer HWP1-f (TCTACTGCTCCAGCCACTGA) and HWP1-r (GTGGAATGGAAGCTTCTGGA) (Exxtend Biotechnology Ltd, Brazil), which is for non albicans(11). PCR assays 186pb generate amplification products for $C$. albicans (ACT1) and for non C. albicans (226pb) (HWP1).

Thermocycling phase consisted of an initial denaturation cycle at $95^{\circ} \mathrm{C}$ for 2 minutes followed by 40 cycles of denaturation at $95^{\circ} \mathrm{C}$ for 15 seconds, primer annealing at $58^{\circ} \mathrm{C}$ for 30 seconds, and primer extension at $72^{\circ} \mathrm{C}$ for 30 seconds. A final primer extension at $72^{\circ} \mathrm{C}$ for 2 minutes was performed, followed by cooling to $4^{\circ} \mathrm{C}$. The samples ran on agarose gel prepared with $2 \%$ Trisbase buffer + Boric acid + EDTA (TBE) diluted in water with adjusted $\mathrm{pH}$. The run was carried out for 50 minutes at $80 \mathrm{~W}$.

\section{Antifungal susceptibility}

The samples of each identified species on ALL group were activated in Falcon sterile tubes containing $5 \mathrm{~mL}$ of SBS and cultivated at $37^{\circ} \mathrm{C}$ for 48 hours. The concentration of Candida employed was $5 \times 10$ [6] UFC/ $\mathrm{mL}$ [12]. Candida inoculums were diluted to a final concentration of 5.0X10 [3] UFC/mL and placed into 96 well microplates (Global Plast ${ }^{\circ}$, Monte Alto-SP, Brazil). Amphotericin B (Sigma Aldrich ${ }^{\circledR}$, Saint Louis, USA) (320 $\mu \mathrm{g} /$ $\mathrm{mL}$ ) was diluted in filtered DMSO and nystatin (Dilecta, João Pessoa-PB, Brazil) $(256 \mu \mathrm{g} / \mathrm{mL})$ on distilled water to achieve the initial concentrations.

In each well microplate, $100 \mu \mathrm{L}$ of Sabouraud Dextrose Broth (SDB) (KASVI ${ }^{\circledR}$, Curitiba, Brazil) were placed. In the next step, $100 \mu \mathrm{L}$ of evaluated antifungal drugs were added to the first well microplate and serially diluted. The microplates were incubated at $37^{\circ} \mathrm{C}$ for 48 hours. Focusing

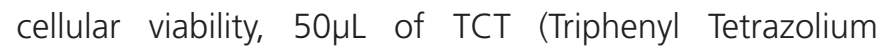
Chloride) dye (Sigma-Aldrich ${ }^{\circledR}$, Saint Louis, USA) were dropped in each well microplate [13]. The reference values to MIC for nystatin were $\leq 4 \mu \mathrm{g} / \mathrm{mL}$ for sensitive isolates, and $\geq 64 \mu \mathrm{g} / \mathrm{mL}$ for resistant isolates Fornari et al. [14]. For amphotericin B, susceptibility was found to be $<1 \mu \mathrm{g} / \mathrm{mL}$, and resistance $>2 \mu \mathrm{g} / \mathrm{mL}$ [14]. C. albicans (ATCC 10221), C. tropicalis (ATCC 750), C. glabrata (ATCC 2001) and C. krusei (ATCC 34135) were used as reference strains. The results of the MIC obtained from the reference samples was $\mathrm{MIC}<4 \square \mathrm{g} / \mathrm{mL}$ for nystatin, and $\mathrm{CIM} \leq 1 \mathrm{mg} / \mathrm{mL}$, for amphotericin B.

\section{Data analysis}

Proportion tests (Chi-Square Pearson and Fisher Exacttests) for evaluation of distribution differences were made to Candida colonization and variables of interest on ALL group. The analysis was performed using IBM SPSS (22.0) software, at significance level of $5 \%$.

\section{Ethical aspects}

This research was approved by the Ethics and Research Committee of the Health Sciences Center of the Federal University of Paraíba with the number of opinion 706.409.

\section{RESULTS}

The mean age of ALL group was 8.1 $( \pm 5.11)$ and the comparative group was $8.2( \pm 4.58)$. The mean DMFT of both groups was 2.04 and dmft was 1.25 . The matched and other variables evaluated in both groups are placed on table 2. The positivity to Candida was higher in the ALL group compared with the comparative one $(p=0.001)$. In both groups, clinical lesions suggesting oral candidosis were not found and apparently none clinical overlaying with oral mucositis on ALL group.

The descriptive analysis of Candida colonization of groups is detached on table 3. CHROMagarCandida suggested the isolation of 8 strains as being C. albicans $(61.5 \%)$, being one collected from the comparative group, followed by C. glabratain five strains (35.7\%), C. krusei on one ALL individual and on one comparative subject $(14.3 \%)$ and one strain of C. tropicalis (7.1\%). According to PCR identification, C. albicans colonies were detected in 13 samples (86.6\%), while only on $2(13.4 \%)$ samples was identified as being non albicans. Of these positive individuals to Candida, 7 (53.8\%) were in induction/reinduction/ consolidation therapy and $6(46.2 \%)$ in maintenance phase. Eight (61.5\%) ALL individuals with positive Candida detection were under the use of systemic steroids at the moment of sampling. Moreover, 2 (15.0\%) individuals were under the use of nystatin and/or amphotericin B to systemic candidosis but without any oral signs of infection. All individuals who had $10^{3} \mathrm{CFU} / \mathrm{mL}$ counts were on the induction phase of chemotherapy. 
Considering age strata, gender, treatment phase, was evident $(p=0.017)$. Positive individuals colonized to hematological variables and OAG indicators, the association Candida presented mucositis indexes mainly ranging from of presence of oral mucositis and positivity to Candida 10 to 14 points. The results of these associations or the lack

Table 2. Descriptive analysis of ALL and comparative groups according some variables ( $n=80)$.

\begin{tabular}{|c|c|c|c|c|}
\hline Variables & Categories & $\operatorname{ALL}(n=40)$ & Comparative $(n=40)$ & $p$-value \\
\hline \multirow{2}{*}{$\begin{array}{l}\text { Stratified } \\
\text { age }\end{array}$} & Upto 6 yrs & $19(46.3 \%)$ & $22(53.7 \%)$ & \multirow{2}{*}{$0.502^{a}$} \\
\hline & Above 6 yrs & $21(53.8 \%)$ & $18(46.2 \%)$ & \\
\hline \multirow{2}{*}{ Gender } & Male & $17(50.0 \%)$ & $17(50.0 \%)$ & \multirow{2}{*}{$1.000^{\mathrm{a}}$} \\
\hline & Female & $23(50.0 \%)$ & $23(50.0 \%)$ & \\
\hline \multirow{2}{*}{ DMFT / dmft } & Under reference & $34(58.6 \%)$ & $24(41.4 \%)$ & \multirow{2}{*}{$0.012^{a}$} \\
\hline & Over reference & $6(27.3 \%)$ & $16(72.7 \%)$ & \\
\hline \multirow{2}{*}{$\begin{array}{l}\text { Candida } \\
\text { Colonization }\end{array}$} & Negative & $27(67.5 \%)$ & $39(32.5 \%)$ & \multirow[t]{2}{*}{$0.001^{\mathrm{B}}$} \\
\hline & Positive & $13(92.9 \%)$ & $1(7.1 \%)$ & \\
\hline
\end{tabular}

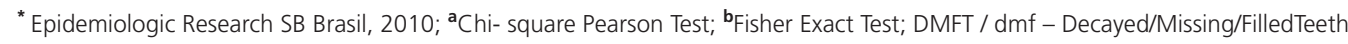

Table 3. Description of quantification and molecular identification of species found on ALL and comparative groups.

\begin{tabular}{|c|c|c|c|}
\hline PatientCode & ChemotherapyPhase & Quantification(CFU/mL) & Strain \\
\hline 2 & Induction & 66 & non albicans \\
\hline 3 & Maintenance & 400 & Candidaalbicans \\
\hline 8 & Maintenance & 33 & Candidaalbicans \\
\hline 19 & Induction & 233 & Candidaalbicans \\
\hline 21 & Maintenance & 66 & Candidaalbicans \\
\hline 22 & Induction & $1.4 \times 10^{3}$ & Candidaalbicans \\
\hline 30 & Induction & $1.3 \times 10^{3}$ & Candidaalbicans \\
\hline 39 & Induction & 766 & Candidaalbicans \\
\hline 40 & Induction & $6.6 \times 10^{3}$ & Candidaalbicans \\
\hline $1^{*}$ & $\begin{array}{c}\text { Comparative } \\
\text { Group }\end{array}$ & 33 & Candidaalbicans \\
\hline
\end{tabular}


of them were placed on table 4 . The table 5 describes the results of microdilution assay and resistance/susceptibility protocol to the employed antifungal drugs. It was found that six out of 11 strains of C. albicans (54.5\%) on ALL group were resistant to nystatin and all species were not susceptible to amphotericin B. All reference strains (ATCC) were susceptible to nystatin and amphotericin $B$ at the same experimental conditions.

Table 4. Evaluation of crossing between positiveness condition to Candida colonization and some variables on ALL group ( $n=40$ ).

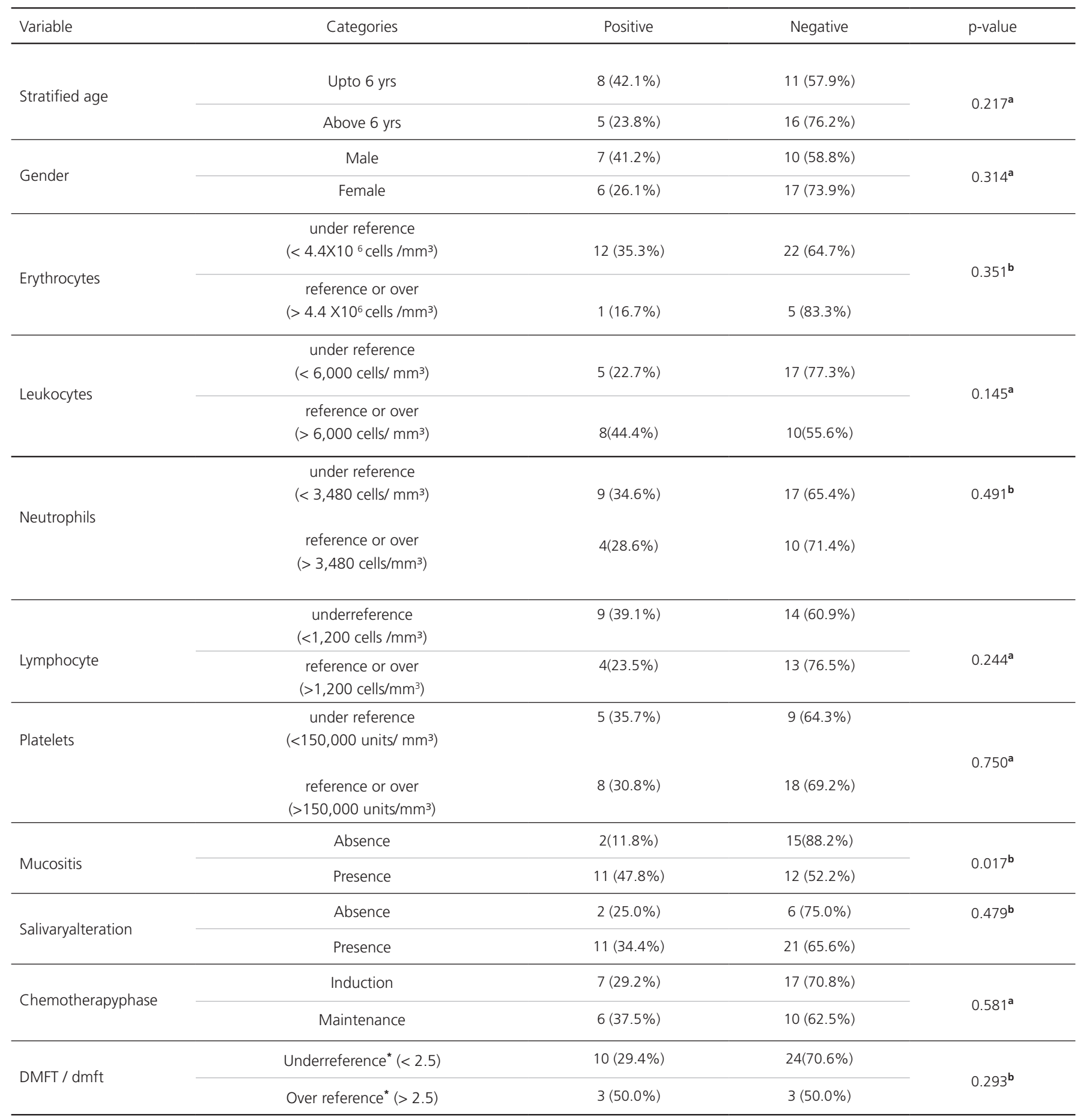

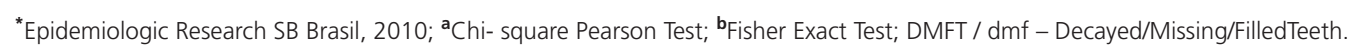


Table 5. MIC values found on molecular identified species of Candida on ALL group $(n=13)$.

\begin{tabular}{|c|c|c|c|}
\hline Drug & Concentration & Candidaalbicans & Non albicans \\
\hline \multirow{5}{*}{ Nystatin } & $64 \mu \mathrm{g} / \mathrm{mL}$ & 1 & -- \\
\hline & $32 \mu \mathrm{g} / \mathrm{mL}$ & 3 & -- \\
\hline & $16 \mu \mathrm{g} / \mathrm{mL}$ & 1 & 1 \\
\hline & $>80 \mu \mathrm{g} / \mathrm{mL}$ & -- & -- \\
\hline & $80 \mu \mathrm{g} / \mathrm{mL}$ & -- & -- \\
\hline \multirow[t]{3}{*}{ AmphotericinB } & $40 \mu \mathrm{g} / \mathrm{mL}$ & - & -- \\
\hline & $20 \mu \mathrm{g} / \mathrm{mL}$ & 5 & 1 \\
\hline & $2.5 \mu \mathrm{g} / \mathrm{mL}$ & 2 & 1 \\
\hline
\end{tabular}

\section{DISCUSSION}

The ALL affects children of all ages, with peak incidence normally happening between two and five years old, with a slight predominance of males corroborating our data with previous distribution found in the literature $[15,16]$. It is extremely important to undergo the dental treatment in ALL individuals and to be screened to oral infections $[17,18]$. Curiously, ALL individuals could present good dental condition compared with other populations as mentioned in our study [19]. In our study both groups had similar access to dental care without any considerable sociodemographic differences [20].

Candidemia in ALL patients could be associated with relapses, prolonged neutropenia and antibiotic administration [3,21]. Curiously, our study showed a lack of association between Candida colonization and hematological parameters. However, considering different types of variables including hematological counts, supportive and treatment conditions could be more relevant [21].CHROMagarCandidacould be used to presumptively identify Candida species. Good compliance between CHROMagarCandidaand other methods of identification was shown but without perfect concordance [22]. In fact, the use of nonmolecular identification methods could be markedly influenced by personal assessment [23]. In fact, molecular identification is an important addition to the conventional identification of Candida species [24].
C. Albicans was the most prevalent strain in the ALL group. A study which evaluated the oral cavity of 111 positive HIV individuals found C. Albicans was the most isolated species (83.5\%) whereas non albicans species were isolated from $16.5 \%$ of colonized individuals [25]. Previously, our group showed increasing of nonalbicans species but on elderly irradiated individuals on head and neck [26].

Other interesting result was the higher counting of CFU of Candida associated with the induction phase of chemotherapy. Probably, induction phase reduces inflammatory response, even on salivary level, favoring Candida colonization. As previously showed, the induction phase had more association of oral complications [19] but them could remain on maintenance phase. The association between the absence of candidosis and mucositis was evident. Previously, it was observed correlation between mucositis and the presence of Candida on ALL patients $[27,28]$.

It is important to carry out antifungal susceptibility testing because of the resistance of Candida strains to certain drugs. Curiously, a previous study found $95 \%$ of their isolates in HIV patients were inhibited by nystatin and amphotericin B [29]. However, emerging resistance of Candida species to antifungal drugs is a real problem. For example, a study with six out of nine children with $A L L$, fungal infection was progressive despite intravenous 
antifungals. The high percentage (21\%) of death from invasive fungal infection among lethal infections in pediatric ALL individuals illustrates the relevance of fungi in this group of individuals [30].

\section{CONCLUSION}

In conclusion, Candida colonization was associated with ALL probably due to its relation to mucositis events being the higher colony counts found during the induction phase of chemotherapy. Candida Albicans was the prevalent strain and resistance to nystatin and amphotericin B was found. PCR fingerprinting could be used as definitive method to identify Candida species in addition to presumptive identification

\section{Acknowlegments}

The authors would like to thank the National Council for Scientific and Technological Development - Conselho Nacional de Desenvolvimento Científico e Tecnológico (CNPq, 474804/20135, 303118/2013-0) - for financial support.

\section{Collaborators}

LC MONTEIRO, conceptualization; data curation; investigation; methodology; visualization; writing-original draft. ILA RIBEIRO, RFB BONAN and AMG VALENÇA, data curation; formal analysis. PP MACIEL, data curation; formal analysis; investigation; methodology; visualization. $A C B$ DULGHEROFF, JR SOUZA and LRC CASTELLANO, data curation; investigation; methodology; visualization; supervision; validation; writing-review \& editing. Y WANDERLEY, conceptualization; data curation; visualization; supervision; validation. PRF BONAN, conceptualization; data curation; funding acquisition; project administration; resources; software; visualization; supervision; validation; writing-review \& editing.

\section{REFERENCES}

1. Miller KD, Siegel RL, Lin CC, Mariotto AB, Kramer JL, Rowland $\mathrm{JH}$, et al. Cancer treatment and survivo rship statistics. CA Cancer J Clin. 2016 Jul;66(4):271-89. doi: 10.3322/ caac. 21349.

2. Javed F, Utreja A, Bello Correa FO, Al-askar M, Hudieb M, Qayyum F, et al. Oral health status in children with acute lymphoblastic leucemia. Crit Rev Oncol Hematol. 2012 Sep;83(3):303-9. doi: 10.1016/j.critrevonc.2011.11.003.
3. Alberth M, Majoros L, Kovalecz G, Borbás E, Szegedi I, Márton $J$, et al. Significance of oral Candida infections in children with cancer. Pathol Oncol Res. 2006;12:237-241.

4. Babu KLG, Mathew J, Doddamani GM, Narasimhaiah JK, Naik LRK. Oral health of children with acute lymphoblastic leukemia: A review. J Orofac Sci 2016;8:3-11.

5. Thein ZM, Seneviratne CJ, Samaranayake YH, Samaranayake LP. Community lifestyle of Candida in mixed biofilms: a mini review Mycoses. 2009 Nov;52(6):467-75. doi: 10.1111/j.14 39-0507.2009.01719.x.

6. Shu M, Ellepola ANB, Samaranayake LP. Effects of two different growth media on the postantifungal effect induced by polyenes on Candida species. J. Clin. Microbiol. 2001;39:2732-2735.

7. De-la-Torre J, Ortiz-Samperio ME, Marcos-Arias C, MarichalarMendia X, Eraso E, Echebarria-Goicouria MA, et al. In Vitro Antifungal Susceptibility of Oral Candida Isolates from Patients Suffering from Caries and Chronic Periodontitis. Mycopathologia. 2017 Jun;182(5-6):471-485. doi: 10.1007/ s11046-017-0112-1.

8. Cheng KKF, Chang AM, Yuen MP. Prevention of oral mucositis in paediatric individuals treated with chemotherapy: a randomised crossover trial comparing two protocols of oral care. Eur J Cancer. 2004 May;40(8):1208-16.

9. Laks D, Longhi F, Wagner MB, Garcia PCR. Survival evaluation of children with acute lymphoblastic leukemia treated with Berlim-Frankfurt-Munich trial. J. Pediatr. 2003;79:149-158. http://dx.doi.org/10.1590/S0021-75572003000200010.

10. Assaf AV, Zanin L, Meneghim MC, Pereira AC, Ambrosano GM. Comparison of reproducibility measurements for calibration of dental caries epidemiological surveys. Cad. SaúdePública. 2006;22(9):1901-1907. http://dx.doi.org/10.1590/S0102-311X 2006000900021.

11. Bustin SA, Benes V, Garson JA, Hellemans J, Huggett J, Kubista $M$, et al. The MIQE guidelines: minimum information for publication of quantitative real-time PCR experiments. Clin Chem. 2009 Apr;55(4):611-22. doi: 10.1373/clinchem.2008. 112797.

12. Oliveira WA, Oliveira FP, Luna GC, Lima IO, Wanderley PA, Lima $\mathrm{RB}$, et al. Antifungal activity of Cymbopogonwinterianusjowitt ex bor against Candida albicans. Braz J Microbiol. 2011;42(2):433-41.

13. Gebremedhin S, Dorocka-Bobkowska B, Prylinski M, Konopka K, Duzgunes N. Miconazole activity against Candida biofilms developed on acrylic discs. J Physiol Pharmacol. 2014 Aug;65(4):593-600.

14. FornariG, Vicente VA, Gomes RR, Dominguez MM, Pinheiro RL, Ferrari $C$, et al. Susceptibility and molecular characterization of Candida species from patients with vulvovaginitis. Braz J Microbiol. 2016 Apr-Jun; 47(2): 373-380. doi: 10.1016/j.bjm. 2016.01.005.

15. Li CR, Chik KW, Ha SY, Lee ACW, Yuen HL, Ling SC, et al. Improved outcome of acute lymphoblastic leukaemia treated by delayed intensification in Hong Kong children: HKALL 97 study. Hong Kong Med J. 2006;12(1):33-39. 
16. Valéra $M C$, Noirrit-Esclassan $E$, Pasquet $M$, Vaysse $F$. Oral complications and dental care in children with acute lymphoblastic leukaemia. J Oral Pathol Med. 2015 Aug;44(7):483-9. doi: 10.1111/jop. 12266.

17. Wilberg P, Kanellopoulos A, Ruud E, Hjermstad MJ, Fosså SD, Herlofson BB. Dental abnormalities after chemotherapy in long-term survivors of childhood acute lymphoblastic leukemia 7-40 years after diagnosis. Support Care Cancer. 2016 Apr;24(4):1497-506. doi: 10.1007/s00520-015-2940-1.

18. Amaral TMP, Campos CC, Moreira, TPS, Leles CR, Teixeira AL, Teixeira MM. Effect of salivary stimulation therapies on salivary flow and chemotherapy-induced mucositis: a preliminary study. Oral Surg Oral Med Oral Pathol Oral Radiol. Oral Surg Oral Med Oral Pathol Oral Radiol. 2012 May;113(5):628-37. doi: 10.1016/j.0000.2011.10.012.

19. Pels E, Mielnik BM. Oral hygiene in children suffering from acute lymphoblastic leukemia living in rural and urban regions. Ann Agric Environ Med2012;19:529-533.

20. Ardenghi TM, Piovesan C, Antunes JLF. Inequalities in untreated dental caries prevalence in preschoolchildren in Brasil. Rev Saúde Pública2013;47:1-8.

21. NicolatoA, Nouér SA, Garnica M, Portugal R, Maiolino A, Nucci $M$. Invasive fungal diseases in patients with acute lymphoid leukemia. Leuk Lymphoma. 2016 Sep;57(9):20849. doi: 10.3109/10428194.2016.1154957.

22. Sariguzel FM, Berk E, Koc AN, Sav H, Aydemir G. Evaluation of CHROMagar Candida, VITEK2 YST and VITEK® MS for identification of Candida strains isolated from blood cultures. Infez Med.2015;23:318-22.

23. Bujdáková H, Melkusová S, Soji I, Mokrás M, MikamiY. Discrimination between Candidaalbicans and Candidadubliniensis isolated from HIV-positive individuals by using commercial method in comparison with PCR assay. Folia Microbiol (Praha)2004;49:484-90.

24. Pfaller MA, Woosley LN, Messer SA, Jones RN, Castanheira M. Significance of molecular identification and antifungal susceptibility of clinically significant yeasts and moulds in a global antifungal surveillance programme. Mycopathologia. 2012 Oct;174(4):259-71. doi: 10.1007/s11046-012-9551-x.

25. Sánchez-Vargas LO, Ortiz-López NG, Villar M, Moragues MD, Aguirre JN, Cashat-Cruz M, et al. Point prevalence, microbiology and susceptibility patterns of oral Candida isolates colonizing or infecting Mexican HIV/AIDS individuals and healthy persons. Rev Iberoam Micol. 2005 Jun;22(2):83-92.

26. Freitas EM, Nobre SA, Pires MB, Faria RV, Batista $A U$, Bonan PR.Oral Candida species in head and neck cancer individuals treated by radiotherapy. Auris Nasus Larynx. 2013 Aug;40(4):400-4. doi: 10.1016/j.anl.2012.11.011.

27. Mendonça RM, Araújo M, Levy CE, Morari J, Silva RA, Yunes JA, et al. Prospective evaluation of HSV, Candida spp., and oral bacteria on the severity of oral mucositis in pediatric acute lymphoblastic leukemia. Support Care Cancer. 2012 May;20(5):1101-7. doi: 10.1007/s00520-011-1190-0.

28. Panghal M, Kaushal V, Kadayan S, Yadav JP. Incidence and risk factors for infection in oral cancer individuals undergoing different treatments protocols. BMC Oral Health. 2012 Jul 20;12:22. doi: 10.1186/1472-6831-12-22.

29 Santolaya ME, Alvarado T, Queiroz-Telles F, Colombo AL, Zurita J, Tiraboschi IN, et al. Active surveillance of candidemia in children from Latin America: a key requirement for improving disease outcome. Pediatr Infect Dis J. 2014 Feb;33(2):e40-4. doi: 10.1097/INF.0000000000000039.

30 Cohn SM, Pokala HR, Siegel JD, McClay JE, Leonard D, Kwon $\mathrm{J}$, et al. Application of a standardized screening protocol for diagnosis of invasive mold infections in children with hematologic malignancies. Support Care Cancer. 2016 Dec;24(12):5025-5033.

Received on: 15/3/2018 Final version resubmitted on: 8/6/2018 Approved on: 30/10/2018 